\title{
AZ ÚSZÁS, MINT AZ EGÉSZSÉG MEGŐRZÉSÉNEK ÉS MEGTARTÁSÁNAK ESZKÖZE
}

Szerzők:

Czeglédi Hanna Orsolya

Debreceni Egyetem (Magyarország)

Lenténé Puskás Andrea ( $\mathrm{PhD}$.)

Debreceni Egyetem (Magyarország)

Müller Anetta (PhD.)

Debreceni Egyetem (Magyarország)

Biró Melinda (PhD.)

Debreceni Egyetem (Magyarország)

Első szerző e-mail címe:

czegledi.hanna.orsolya@gmail.com

\section{Lektorok:}

Pucsok József Márton (PhD.)

Debreceni Egyetem (Magyarország)

Dr. habil Fenyves Veronka (PhD.)

Debreceni Egyetem (Magyarország)

Czeglédi H. O., Lenténé Puskás A., Müller A., Biró M. (2020). Az úszás, mint az egészség megőrzésének és megtartásának eszköze. Különleges Bánásmód, 6. (2). 35-47. DOI 10.18458/KB.2020.2.35

\section{Absztrakt}

A mozgásszegény életmód, a nem megfelelő táplálkozás, a stressz egészségkárosító hatásai ellen érdemes különböző megelőző eljárásokat tenni. Ennek kiváló eszköze lehet az úszás, amit az emberek az egyik legegészségesebb sportágnak tartanak. Miként vélekednek az emberek erről a mozgásformáról? Tisztába vannak-e, hogy milyen területeken fejti ki sokoldalú pozitív hatását? Ezekre, és hasonló kérdésekre kerestük a választ a kutatásunkban. A kutatásban 126 fő vett részt, akik mind, 40 év felettiek. Módszerünk az online kikérdezés volt. Eredményeink azt mutatják, hogy hogy az úszás sokoldalú, pozitív hatásai nagyrészt ismertek az emberek előtt, de ennek ellenére vannak még olyan problématerületek, amit érdemes tovább vizsgálni.

Kulcsszavak: úszás, egészség, egészségmegőrzés

Diszciplina: sporttudomány, egészségtudomány

\section{Abstract}

SWIMMING AS A TOOL FOR PRESERVING AND MAINTAINING HEALTH

It is worth taking various preventive measures against the sedentary lifestyle, inadequate nutrition, and the harmful effects of stress on health. Swimming can be an excellent tool for this, which people consider 
to be one of the healthiest sports. How do people feel about this form of movement? Are you aware of the areas in which it is having a multifaceted positive impact? We sought answers to these and similar questions in our research. The study involved 126 people, all over the age of 40. Our method was an online questionnaire. Our results show that the multifaceted, positive effects of swimming are largely known to people, but there are still problem areas that are worth further investigation.

Keywords: swimming, health, health preservation

Disciplines: sport sciences, health sciences

A magyar lakosságnak sajnos kiemelkedően rossz az egészségi állapota. Mindezt számos összetevő befolyásolja, mint a mozgásszegény életmód, a nem megfelelő táplálkozás, de a stressz is egy komoly rizikófaktor az emberek életében. Mindez olyan következményekkel jár, amelynek társadalmi hatásait egyre inkább érzékeljük a mortalitási statisztikákon, a szabadidős szokások drasztikus megváltozásán, és a népegészségügyi adatokon (Népegészségügyi jelentés, 2008; Egészségjelentés, 2015, Magyarország 2015, European Health for All database, 2016). Mindennek következményeivel számos területen szembesülünk, mint pl. a csökkenő munkavégző képesség, az elhízás, a cukorbetegség, a magas vérnyomás, tartáshibák, anyagcserezavarok, neurózis és még sorolhatnánk a különféle ártalmakat, melyek jelentősen kihatnak az egyénre és ezáltal a társadalom egészére.

Hazánkban a lakosság rossz egészségi állapotáért több betegségtípus is felel, de az első helyen, a szívés érrendszeri megbetegedések állnak, melyek a halálozás közel 50\%-áért felelek. A második helyre a rosszindulatú daganatos megbetegedések kerülnek. Magyarországon az összes halálozás háromnegyedéért, a 65 éves kor előtt bekövetkező korai halálozás több mint kétharmadáért a keringési rendszer betegségei és a daganatos megbetegedések voltak felelősek. A 2014-ben meghalt 126 ezer ember felének keringési betegség okozta a halálát. (Népegészségügyi jelentés, 2008; Egészségjelentés, 2015; Magyarország 2015). A KSH adatai szerint az 1949-
2007 között növekedett meg a szív-és érrendszeri és a daganatos megbetegedések száma, köszönhető ez a felgyorsult, modern világnak, a már korábban említett helytelen táplálkozásnak, a mozgásszegény életmódnak (KSH, 2007). 2011-ben a halálozás több mint feléért $(50,45 \%)$ a szív- és érrendszeri megbetegedések feleltek, az esetek negyedéért $(25,35 \%)$ a daganatos megbetegedések voltak a felelősek (KSH, 2012b). Ki kell emelni a magasvérnyomás-betegséget, mely a szív és érrendszeri betegségek egyik leggyakoribb kockázati tényezője. Hazánkban ez komoly népegészségügyi problémának számít, a második legnagyobb veszteséget okozó egészségkockázat (Magyarország 2015), a krónikus betegségek közül a legelterjedtebb a lakosság $31 \%$-át érinti. Modern világunk egyik legnagyobb problémájának a daganatos megbetegedések számának emelkedését tartják, ami alól hazánk sem kivétel. A férfiak és a nők együttes rákhalálozási világstatisztikájában a tüdőrák vezet, ahol sajnos mi magyarok vagyunk az elsők. Tüdőrák következtében hal meg minden hetedik rákbeteg (kb. 1,1 millió évente) (Tompa, 2011). Közrejátszik ebben a dohányzás, ugyanis hazánkban rendkívül nagy számban vannak jelen a dohányosok. A Gallup Intézet adatai szerint a magyar lakosság 53,4\%-a dohányzik. 2012-ben a KSH adatai szerint, 21746 halálozás volt, ami a dohányzással összefüggésbe hozható. 2030-ra a WHO szerint, 8,3 millió halál oka áll kapcsolatban a dohányzással (Mathers és Loncar, 2006). A dohányzás a világon évente több 
mint 500 millió dollár értékủ gazdasági kárt okoz, a meglévő problémák mellett (WHO 2013). A dohányzás, ma Magyarországon az egyik legelterjedtebb és legsúlyosabb szenvedélybetegség az alkoholizmus mellett. 2014-ben került sor a második egészségügyi lakosság felmérésre. A számok azonban még mindig elkeserítőek. A leggyakoribb betegség a magas vérnyomás maradt, amiről a lakosság 31\%-a vallott, a mozgásszervi betegségek, ahol 21\%-ban a derék vagy hátfájást említették. Az ízületi kopás 17\%-ban, a nyaki, gerinc problémák 11\%-ban jelentek meg a kérdőívet kitöltők között. A csontritkulás leginkább az idősek körében, azon belül inkább a nők életében van jelen, az 55 év felett lévő nők 24\%-ánál. Ezek után a harmadik helyen áll a szív- és érrendszeri megbetegedések, minden tízedik embernél mutattak ki szívritmus zavart, minden huszadiknál szívkoszorúér megbetegedést, pedig mindez megelőzhető lenne. Sajnos mára a népbetegségek közt kell megemlítenünk a napjainkra egyre több embert érintő cukorbetegséget, a zsíranyagcsere-zavart, és az elhízást. Hazánkban a felnőtt lakosság 54\%-a túlsúlyos (Egészségjelentés, 2015), azonban más adatok (OTÁP, 2014) $10 \%$-kal magasabb adatokról is beszélnek, ez akár 5 millió embert jelent. Feltételezés szerint az idősödó korosztályban, ennél is magasabb számokról lehet szó, hiszen a lelassult anyagcsere, a nehézmozgás következtében még nagyobb a kockázat az elhízásra. A gyermekeknél egyre hamarabb jelenik meg az elhízás. Minden korosztályban az emberek egy harmada elhízott (18-34 éves nők), a kor előrehaladtával csak növekednek ezek az arányok, 35-64 éveseknél már kétharmad arányban vannak a túlsúlyosok száma. Az elhízás számos betegséget vonz magával, többek között a keringési megbetegedések, a daganatos és mozgásszervi megbetegedések ezek mellett a cukorbetegséget is. Magyarországon feltehetőleg 740.000 cukorbeteg van, sajnos a prevalenciája nő (Kemper és mtsai, 1999; Egészségjelentés, 2015). Fontos megemlíteni a mozgásszervi megbetegedéseket, ami szintén jelentősen befolyá- solja az emberek életminőségét. A különböző mentális zavarok, mint a depresszió, szorongás, pánikbetegség, vagy a fóbiák ugyancsak jelentős népegészségügyi kockázattal járnak. A depresszió olyan mértékben terjedt el, hogy a WHO becslése szerint, 2020-ban a legelterjedtebb betegség lesz az egész világon. Napjainkban a felnőttek $27 \%$-a szenved valamilyen mentális elváltozásban. A KSH 2014ben készült felmérése során az is kiderül, hogy a megkérdezettek $12 \%$-a számolt be arról, hogy allergiában szenved, valamint allergiás megbetegedés lép fel nála, 5\%-ban az asztma, 4\%-ban a krónikus hörghurut jelent meg (KSH, 2014).

Statisztikai elemzésekből kiderül, hogy Magyarország népességének átlagéletkora folyamatosan növekszik. Az öregedési folyamattal arányosan növekszik a krónikus betegségek magas száma, mely mind makro- és mikrotársadalmi szinten gazdasági és szociális terhet jelenthet (Semsei, 2008; Cserhátiné, 2010). A hazai és nemzetközi kutatások azt is igazolják, hogy az időskori megbetegedések legnagyobb számát a szív- és érrendszeri, valamint a mozgatószerv-rendszeri betegségek adják (Bálint, 2003, 2007; Apor, 2011; Sagiv, 2009), továbbá, hogy a vezetô halálok a szív- és érrendszeri betegségek képviselik, ezért egyre több kutatás (Juhász és tsai, 2015; Kopkáné és tsai 2015) erre fókuszál.

\section{A mozgás, az úszás egészségre gyakorolt sokoldalú hatása}

$\mathrm{Az}$ elmúlt években számos tanulmány foglalkozott a fizikai aktivitás, a mozgás egészségre gyakorol kedvező hatásával (Biró, 2015), sőt kiemelten az egyik legegészségesebb sportág az úszás vonatkozásában (Biró és tsai, 2006; Biró és tsai, 2007a,b; Biró, 2011). Régóta foglalkoztatja ugyanis a kutatókat annak bizonyítása, hogy a fizikai aktivitás milyen sokoldalúan, és pozitívan hat az emberi szervezetre. Bizonyították már hatását a napjainkban leginkább jellemző betegségek, a szívés érrendszeri betegségek, bizonyos fajta rák, a 2 . 
típusú cukorbetegség megelőzésében és rehabilitációjában (Pikó és Keresztes, 2007; Somhegyi és tsai, 2006; Kiss, 2003). Igazolták, hogy a rendszeres (aerob) testmozgás csökkenti a nyugalmi vérnyomást egészséges és magas vérnyomású személyeknél is (Wilmore és Costill, 2004). Hosszútávú követéses vizsgálatok eredményei azt mutatták, hogy a rendszeresen sportolóknál csökken a szívinfarktus, és a szív érrendszeri betegség előfordulása (Nurses Health Study, Manson-Hu-Rich-Edwards, 1999; Tanasescu és tsai, 2002), sőt még idős korban is (Bijnen és tsai, 1998). Hasonló követéses vizsgálatok számolnak be arról is, hogy az aktív életmódot élőknek 30-40\%kal kisebb az esélye, hogy vastagbélrák, vagy mellrák fejlődjön ki náluk, mint az inaktív életmódot folytatóknál (Norwegian study, ThuneLund, 1994; Women's Health Study, Lee és tsai, 2001; Nurses Health Study, Rockhill és tsai, 1999). A rendszeres fizikai aktivitás számtalan betegségnek segít csökkenteni a kialakulást, a szív-és érrendszerei megbetegedés, daganatos és mozgásszervi megbetegedések, valamint késlelteti a csontritkulás kialakulását. Jelentős szerepe van a testsúly-szabályozás és az elhízás megelőzése szempontjából is. A mozgás további előnye, hogy csökkenti a mozgásszervi betegségek előfordulását, késlelteti a csontritkulást (Rácz, 2005). A mentális egészség megőrzésében is központi szerepet tölt be, véd a depresszió, szorongás és az alvászavarok ellen (Makra és Balogh 2020). A rendszeres testmozgás növeli a csontok, ízületek stabilitását; csökkenti az oszteoartritisz okozta panaszokat, elősegíti a csonttömeg maximalizálását, és amennyiben ez az aktivitás az egész felnőttkorban megmarad, akkor magasabb csont ásványi anyag szintről indul a csontvesztés, ez csökkenti a csontritkulás kialakulásának valószínűségét (Szőts és tsai, 2004; Martos, 1998). Több tanulmányunkban (Biró, 2006; Biró, 2007) is kiemeltük ennek fokozott érvényesülését úszás hatására. Olyan kedvező biológiai változások jönnek létre, ideg-, izom-, csontrendszer, valamint az egyéb szervek, szervrendszerek funkcionális tulajdonságaiban, mely hatására az úszás mozgásanyaga mind a prevencióban, mind pedig a rehabilitációban fontos szerepet kaphat. További kutatásainkban bizonyítottuk, hogy a fizikai aktivitás fokozza a kedvező élettani adaptációs folyamatokat, melynek pozitív hatásai már mérsékelt intenzitású fizikai aktivitás révén is elérhetők (például 30 perc gyaloglás vagy 15 perc futás heti legalább öt alkalommal) (Kopkáné és tsai, 2015; Juhász és tsai, 2015). Már korábban is említettünk, hogy komoly népegészségügyi kockázati tényező a depresszió, a szorongásos zavarok és a krónikus stressz, de ezen negatív lelki folyamatok egyik legjobb gyógymódja a rendszeres fizikai aktivitás (Berger és Owen, 1988; Berger és Owen, 1994; Kerr és Vlaswinkel, 1995; Bond és tsai, 2002; Balogh és tsai, 2008; Fenyves és tsai, 2020). Saját kutatásunk eredményeiből, mind pedig a szekunder kutatások adataiból jól látható, hogy a rendszeres testedzésnek, sportolásnak az egészségvédő szerepe kiemelkedő. Mindezen eredmények is alátámasztják a mozgás fontosságát, és élethosszig tartó aktív életmód gyakorlását. Ráadásul az úszás life-time sport, így akár az óvodás kortól idős korig alkalmas mozgásforma a nevelésre, akár a család minden tagja tudja együtt űzni, mely azért is fontos, hiszen a család meghatározó szerepét a nevelésben több kutatás is megerôsíti (Kőnigh és tsai, 2019, Murray és tsai, 2019, Laoues, 2017, Bocsi, 2017, Mező, 2018; Czeglédi 2018a,b).

\section{Módszer}

Kutatásunk során az úszás hatására koncentráltunk. Célunk az volt, hogy megvizsgáljuk, hogy a 40 év feletti emberek miként vélekednek az úszásról, és információt kapjunk arról, hogy életükben milyen szerepet kap. Kíváncsiak voltunk, hogy mit gondolnak az úszás egészségre gyakorolt szerepérôl, és miben, milyen területeken látják a hatását. Pontosabban, mennyire vannak tisztába az úszás 
egészség megőrzésében és megtartásában, valamint a rehabilitációban betöltött szerepével az egyes betegségek kapcsán. Ehhez az online kikérdezés módszerét választottuk, mivel ez a módszer a legalkalmasabb egyének, esetleg csoportok együttes ismereteinek, véleményeinek, attitűdjeinek, élményeinek, motívumainak, életmódjának a felderítésére. A kérdőív tartalmazott, zárt, és nyitott kérdéseket, rangsoroló, és Likert skálás kérdéseket, valamint feleletválasztást igénylő kérdéseket.

\section{Minta}

A kutatás alanyai 40 év felettiek. Összesen 126 fó vett részt a vizsgálatban. Átlagéletkoruk 49,84 év, (szórás 8,5, maximum: 88 év). Úgy véltük, hogy 40 év felett az emberek már másként gondolkodnak az egészségükről, hiszen már megjelennek azok a problémák, melyek a társadalmunkat jellemzik. A minta 33\%-a úgy nyilatkozott, hogy nem jellemző rá semmilyen betegség előfordulása, míg 67\%uknál előfordult valamilyen betegség. A stressz a leggyakoribb, a mintában résztvevők 21,4\% jelölte, amit mozgásszervi betegségek (18,25\%), és az elhízás $(17,4 \%)$ követ. Magas vérnyomás betegsége a minta 15,5\%-ának van, míg allergiája vagy asztmája 15\%-nak. A szív és érrendszeri megbetegedések aránya a vizsgálati mintában $11 \%$, légzőszervi megbetegedésé $7,1 \%$, cukorbetegségé $5,5 \%$, Csontritkulás $4,7 \%$, és daganatos betegség előfordulása 3,9\%. 3,9\%-uknál egyéb betegség áll fenn, míg $0,8 \%$ nem nyilatkozott a kérdés kapcsán. A mintába bekerülőket megkérdeztük arról, hogy mennyire érzik magukat egészségesnek. 1-5-ig skálán kellett értékelni, ahol átlag 3,91-re értékelték saját egyészségüket (szórás 0,74). Hozzátartozik még a minta jellemzéséhez, hogy 70,4\%-a sportol, mozog, míg 29,6\%-a nem. Mivel a vizsgálatunkban az úszást, mint mozgásos tevékenységet vizsgáltuk, így rákérdeztünk arra is, hogy vízi mozgásos tevékenységet (úszás, vízi aerobik, vízi jóga, stb.) milyen gyakorisággal végeznek. 38\%-uk nem végez ilyen jellegú mozgást, 16,6\%-uk évente, 12,7\%-uk félévente, $10,3 \%$-uk havonta, $13,5 \%$-uk hetente, és 7,9\%-uk naponta.

\section{Eszközök}

A kvantitatív eljárás során előtesztelt kérdőívet alkalmaztunk, melyben számos szabadidővel, és sportolási, üdülési szokással kapcsolatos kérdés szerepelt. Az úszással kapcsolatos vélemény felmérése csak egy kis részét képezték a komplex vizsgálatnak. Az alábbi témakörök kaptak helyt a kérdőívben az egészségmegőrzés lehetőségei, egészségi állapot, sportolási szokások különös tekintettel a vizes mozgásformákra, szabadidő eltöltés módja, valamint az úszás hatása. Jelen tanulmányunkban kizárólag az úszás szervezetre gyakorolt hatásával kívánunk foglalkozni, és ennek az eredményeit mutatjuk be.

\section{Eljárás}

A kikérdezésre, mely során az egyének ismereteire, véleményeire voltunk kíváncsiak, valamint attitúdjeinek, élményeinek, motívumainak, életmódjuknak a felderítésére, 2019-ben került sor. Leginkább leíró statisztikával dolgoztunk.

\section{Eredmények}

A vizsgálatban részt vevők véleményére voltunk kíváncsiak, hogy mennyire vannak tisztába az úszás egészségre gyakorolt hatásaival. Erre vonatkozóan elsőként egy egyszerú kérdést tettünk fel, ahol konkrétan erre kérdeztünk rá. 1-7-ig kellett osztályozniuk mindezt, ahol az átlag 5,42 (szórás 1,7) lett. Ezt követően pedig az egyes betegségtípusok kapcsán kérdeztük meg a hatást, valamint az úszás rehabilitációban és a prevencióban betöltött szerepét. Ezeknél a kérdéseknél ugyancsak 1-től 5ig kellett osztályozniuk, hogy mennyire vélik hasznosnak az úszás szerepét (nagyon hasznos, je- 
lentős mértékben, közepesen, kis mértékben, egyáltalán nem hasznos).

Az úszás egyik legdominánsabb hatása a mozgató-szervrendszerben bekövetkező pozitív változások. Ezek döntő fontosságúak nemcsak a fiatalok fejlődésében, hanem idősebb kor felé haladva egyre inkább, hiszen az úszás elősegíti a csontok megvastagodását, és ezáltal az egész nő a csontok szilárdsága, teherbíró képessége, ásványi anyag tartalma. Idős korra erôsebb, teherbíróbb, minőségében jobb csontozatot figyeltek meg azoknál, akik szabadidejükben úsznak (Bíró 2011). Az eredményeink azt mutatják (lásd: 1. ábra), hogy a vizsgálat alanyai is nagyrészt tisztában vannak azzal, hogy az úszásnak pozitív hatása van a testünk támasztószerv-rendszeré. A minta 89,6\%-a véli úgy, hogy nagyon, vagy jelentős mértékben hasznos az úszás ezen problémák esetén (nagyon hasznos $67,4 \%$, jelentős mértékben $22,2 \%$ ).

1. ábra $A_{z}$ úszás szerepének (basznosságának) megitélése gerincproblémák esetén, százalékos érték (forrás: a Szerzőok)

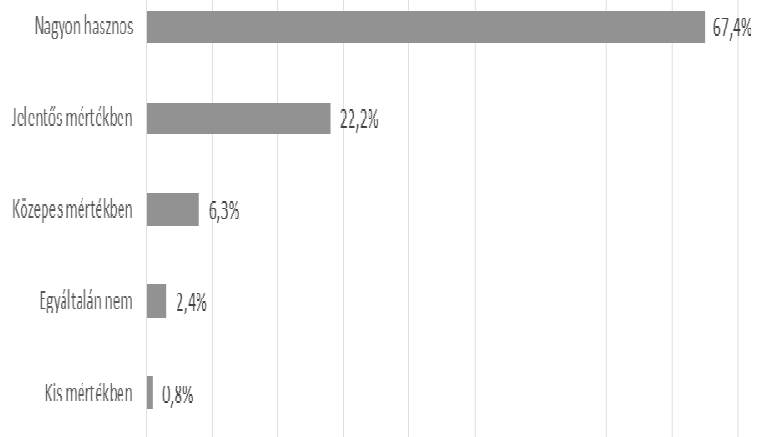

Érdekes eredményt mutatnak a csontritkulás kapcsán a válaszok. Az látható, hogy az emberek már nincsenek annyira tisztában a csontrendszerben lezajló pozitív változásokkal, mint annak a külsô, inkább a mozgató- és tartórendszerre kifejtett hatását illetően. A válaszadók mindössze 19,8\%-a szerint nagyon hasznos, és 24,6\%-a jelölte, hogy szerinte jenetôs pozitív hatása lehet az úszásnak $\mathrm{Ez}$ összesen 44,4\%, ami az előző kérdésnél erre a 2 kategóriára adott válaszok kevesebb mint fele. A válaszadók 22,2\%-a közepes mértékúnek, 20,6\%-a pedig kis mértékünek tartja e területre kifejtett hatást. $11,9 \%$ szerint pedig nincs semmilyen hatása az úszásnak a csontritkulásra.

2. ábra $A z$ üszás szerepének (basznosságának) megitélése csontritkulás esetén, százalékos érték (forrás: a Szreröo)

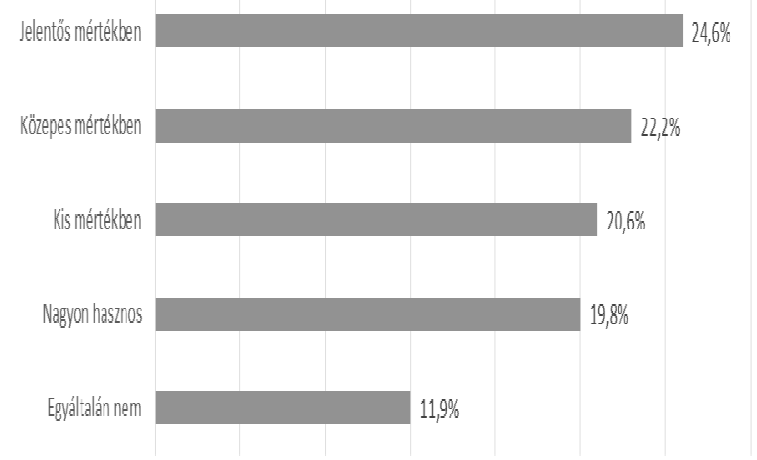

Mivel az úszásnak kiemelt szerepe van a testtartás javításában (Bíró, 2011), ezért nemcsak a megelőzésben, hanem a rehabilitációban is fontos szerepet tölt be. Mivel a csont, ízületi bántalmak, gerincproblémák és balesetek, mûtétek utáni terápiára is alkalmas, ezért nem véletlen, hogy mind a gerincbántalmakban szenvedőknek, mind pedig baleseti rehabilitációban részesüló pácienseknek is javasolják. Ezen okból külön megkérdeztük, hogy mit gondolnak, milyen mértékben segíti a tartás javítását, valamint milyen szerepet játszik a rehabilitációban. A tartásjavításban betöltött szerepénél a minta 59,5\%-a nagyon hasznosnak véli, 22,2\%-a jelentős mértékben, $11,1 \%$-a pedig közepes mértékben tartja hasznosnak, 4,8\% kis mértékben, 1,6\% pedig egyáltalán nem. A többség 
$(81,7 \%)$ tehát kiemelkedőnek tartja az úszás ezen szerepét, habár érdekes, hogy kisebb mértékben, mint a gerincproblémák esetében. A sérülések utáni rehabilitációban való szerepét már nem értékelik olyan jelentősnek, mint az előzőeket. A válaszadók 44,4\%-a véli nagyon hasznosnak, 32,5\%-a pedig jelentős mértékben. Ez a minta 76,9\%-a. Az előzőekhez képest viszont nőtt azok száma, akik úgy vélik, hogy csak közepes $(15,8 \%)$, kis $(3,2 \%)$ mértékben, vagy akár egyáltalán nincs $(3,2 \%)$ is hatása (lásd: 3. ábra). A vizsgálatban résztvevók közel negyede $(18,25 \%)$ szenved valamilyen mozgásszervi betegségben.

3. ábra Az úszás szerepének (basz̧nosságának) megitélése a rehabilitációban, százalékos érték (forrás: a Szerzőok)

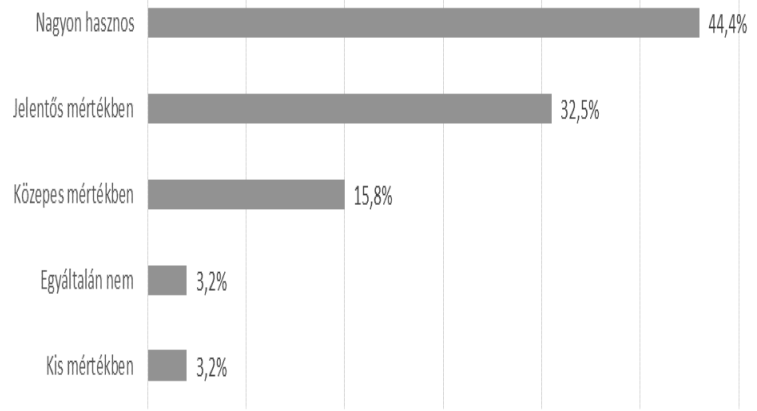

Az úszás ennek az egyik leghatékonyabb gyógymódja (Bíró, 2011). A minta 50\%-a tartja nagyon hasznosnak, 32,5\%-a jelentős mértékűnek szerepét a mozgásszervi problémák esetében. 11,9\%-uk csak közepes mértékben tartja hasznosnak, 3,2\% kis mértékben, 1,6\%, pedig egyáltalán nem (lásd: 4. ábra).

Megkérdeztük, hogy miként vélekednek az úszás szerepéről az ízületi betegségek esetében. A minta $31,7 \%$-a nagyon hasz-nosnak tartja, $28,5 \%$-a jelentős mértékben előnyösnek, mag 24,6\%- csak közepes mértékben hasznosnak. 8,7\% kis mérték- ben véli előnyösnek szerepét, míg a válaszadók 5,5\%-a egyáltalán nem.

A szív- és érrendszeri megbetegedések száma, valamint az a miatti halálozás hazánkban a legmagasabb, a vizsgálati mintában ennek előfordulása $11 \%$. Az úszás, valamint a közeg, keringésre, és ezáltal a szívre gyakorolt pozitív hatása kiemelkedő. Nemcsak, hogy megszaporodik a szív hajszálér-hálózata, de ezáltal csökken a szívinfarktus lehetősége, és az infarktus utáni felépülés is gyorsabb, megelőzhető a szívbetegségek kialakulása (Hammerman, 1983), és a szív- és érrendszeri betegségek kockázatai rendszeres fizikai aktivitással, úszással csökkenthetők.

Nemcsak, hogy megszaporodik a szív hajszálérhálózata, de ezáltal csökken a szívinfarktus lehetősége, és az infarktus utáni felépülés is gyorsabb, megelőzhető a szívbetegségek kialakulása (Hammerman, 1983), és a szív- és érrendszeri betegségek kockázatai rendszeres fizikai aktivitással, úszással csökkenthetők.

4. ábra $A z$ üszás sžerepének (basznosságának) megitélése a mozgásszervi problémák esetében, százalékos érték (forrás: a S zerzö́k)

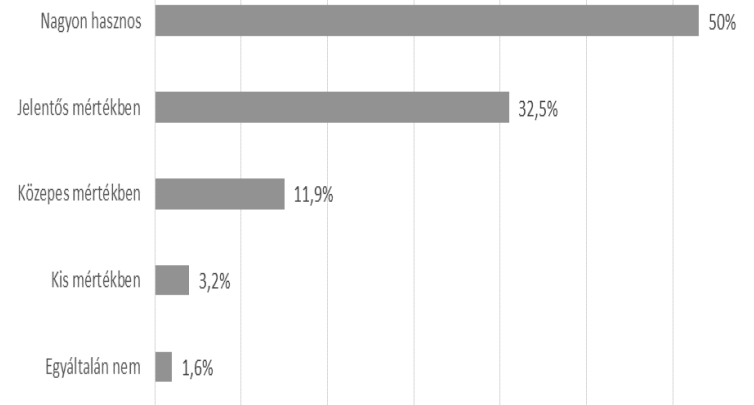

Érdemes még megemlíteni, hogy az úszás lassítja a szív és az erek öregedését, csökkenti az érelmeszesedések kialakulásának veszélyét. Érdekes eredményt kapunk az eredmények vizsgálatakor. 
Habár hatásosnak tartják az úszást, (30,9\% nagyon hasznosnak, 39,7\% jelentős mértékben véli hasznosnak), de mégsem olyan mértékűnek vélik a szerepét, mint pl. a gerincproblémák esetében. A minta 19,8\%-a közepesen, 5,5\%-a kis mértékben, 3,2\%-a egyáltalán nem tartja hatékonynak ((lásd: 5 . ábra). Hasonló eredményeket kaptunk a magas vérnyomás betegség esetében is. A minta 19\%-a véli csak nagyon hasznosnak, 27,7\%-a pedig jelentős mértékben. 27,7\% csak közepesen, 14,3\% kis mértékben tartja csak hatékonynak az úszást. A válaszadók 10,3\%-a gondolja úgy, hogy egyáltalán nincs hatással az úszás a magas vérnyomás betegségre.

A másik nagyon jelentős betegségtípus hazánkban a daganatos megbetegedések, ami a haláloki statisztikában sajnos elókelő helyet foglal el. A mintában is előfordult és daganatos betegség (3,9\%). Az eredményeink azt mutatják, hogy a válaszadók még nem kötik össze olyan mértékben a mozgás (úszás) pozitív hatását a daganat esetében, mint a gerincproblémáknál, vagy akár a szív érrendszeri megbetegedés kapcsán. 34,1\%-uk egyáltalán nem tartja hasznosnak az úszást ezen betegség kapcsán, pedig a megelőzésében és a rehabilitációban is fontos lehet. Habár, még nem minden rákbetegség kapcsán sikerült kimutatni hatékonyságát, de már több betegségtípusnál igen. A válaszadók mindössze 23,8\%-a tartja lényegesnek (nagyon hasznos $10,3 \%$, jelentős $13,5 \%$ ).

A stressz nemcsak napjaink leggyakoribb betegsége, de a mintában is ez fordult eló legnagyobb mértékben, a résztvevook 21,4\%-ánál. Az úszás hatásai közt meg kell említeni, azt is, hogy a kellő és örömteli testmozgás a pszichoszomatikus betegségek (lelki eredetû testi betegségek) kialakulása ellen is védelmet jelent, stressz-oldó hatása bizonyított (Bíró, 2011). A vizsgálati mintában az emberek az 70,6\%-a van tisztába ezzel. 46,8\%-uk véli úgy, hogy nagyon hasznos, $23,8 \%$-uk szerint pedig jelentős hatása van. A megkérdezettek 18,5\%-a szerint közepes, 6,3\%-a szerint kismértékben érzékelhető a hatása, míg 3,9\% szerint egyáltalán nincs pozitív hatással az úszás a stressz kezelésére (lásd: 6. ábra).

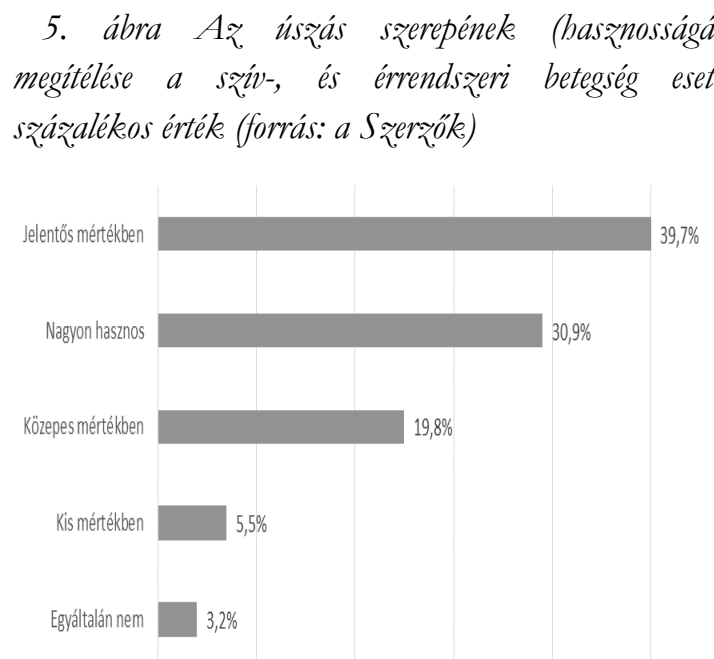

6. ábra $A z$ úszás szerepének (hasznosságának.) megitélése stressz levezutésében, százalékos érték (forrás: a Szerzők)

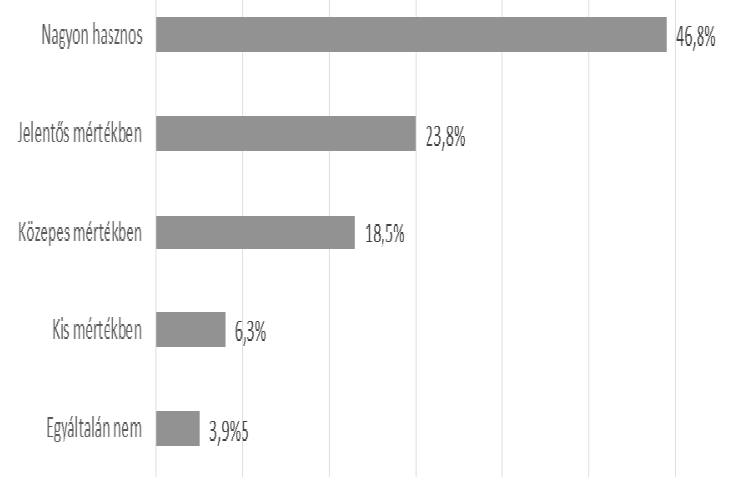

Jóllehet a légzőszervi panaszokkal küzdők számara a legtöbb mozgásforma nem előnyös, de ez nem mondható el az úszásról. Természetesen ez betegségtípustól is függ, de a vízben végzett mozgás 
pozitív hatással van a légzőszervi múködésére. Az úszók között a mozgás okozta asztma ismeretlen, mivel úszás közben a belélegzett levegő rendszerint meleg és párás. Közvetlenül a víz felszíne fölötti tiszta, por-, és füstmentes páradús levegő, mind az asztmás, mind, pedig az allergiában szenvedóknek is kedvez. Ez nem teljesen tudott a vizsgálatban résztvevőknél. Mindössze a megkérdezettek fele $(54,6 \%)$ vallotta azt, hogy nagyon $(26,9 \%)$, vagy jelentős mértékben $(27,7 \%)$ hasznos. 19,8\%-uk szerint közepesen, 11,9\%-uk szerint kis mértékben, míg 12,7\%-uk szerint egyáltalán nem hasznos. Az elhízás kapcsán a résztveők 42,8\%-a véli úgy, hogy jótékony hatása van a vizi mozgásformának, 32,5\%-uk szerint jelentős, 12,7\%-uk szerint közepes, 10,3-k szerint kicsi a hatásfoka, míg 0,8\%szerint nincs is.

7. ábra Az üszás szerepének (basznosságának) megitélése az asztmás betegség esetében, squáalékos érték (forrás: a S žerzoók)

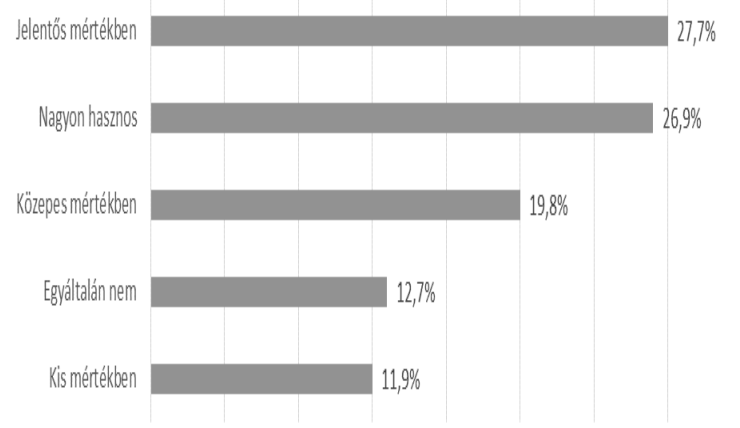

A cukorbetegség kapcsán már a jelentős (23\%) és közepes mértékben (23\%) tartják hatékonynak. 20,6\%-uk szerint nagyon, $19 \%$-uk szerint kis mértékben, míg 13,5\%-uk szerint egyáltalán nem hatásos.

A vízben végzett mozgás során le kell győzni a közeg ellenállását, így intenzívebb munka végezhetô, mint a szárazföldön. Ennek ellenére, mégis azt mondhatjuk, hogy kevésbé megterhelő, hisz a vízben könnyebb a hőleadás és kevesebb az izzadás. A felhajtóerô pedig csökkenti a testre nehezedő súlyt, így kíméli az ízületeket, emiatt pedig csökken a sérülésveszély, valamint a gerincoszlopra és a csontozatra is kisebb terhet helyez. Ez az egyik oka, hogy mind túlsúlyos mind pedig idős személyeknek is javasolt.

A betegségeken túlmenően megkérdeztük azt is, hogy a vizsgálat alanyai mennyire vélik hatékony mozgásformának az úszást idősek esetében. A minta kétharmada tartja hatékonynak (nagyon hasznos 34,1\%, jelentôs mértékben 41,3\%), 17,5\%a közepesen hasznosnak, míg 4,8\%-uk kismértékben, 1,6\%-uk pedig egyáltalán nem véli annak (lásd: 8. ábra).

8. ábra $A z$ úszás szerepének (baszৃnosságának) megitélése idösek esetében, százalékos érték. (forrás: a Szerrók)

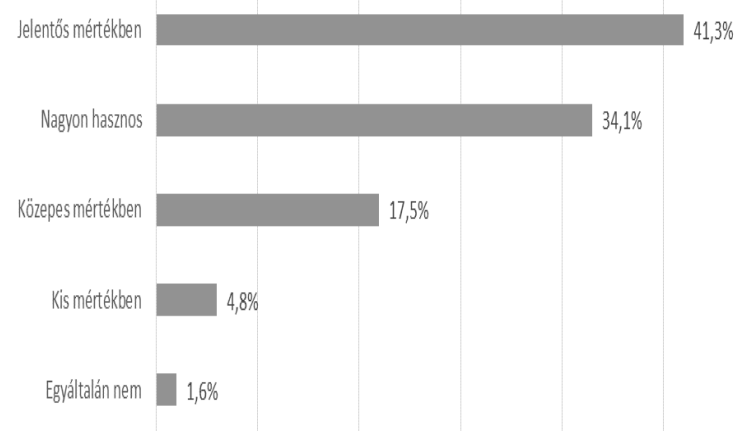

\section{Konklúziók}

Kutatásunk során arra voltunk kíváncsiak, hogy mennyire vannak tisztába az úszás egészségre gyakorolt hatásaival az emberek. Erre vonatkozóan számos kérdést tettünk fel, ami megmutatta, hogy számos betegségtípus esetén pozitívan vélekednek az úszásról. A hatások közül leginkábba a tartórendszerünkben bekövetkező pozitív változáso- 
kat látják, a minta 89,6\%-a vélte úgy, hogy nagyon, vagy jelentős mértékben hasznos az úszás ezen problémák esetén. A testtartás javításban betöltött szerepét is sokan $(76,9 \%)$ értékelték nagyon, vagy jelentős mértékben hasznosnak. Ugyancsak hasznosnak $(82,5 \%)$ tartják a mozgásszervi problémák esetében is. Az is látható, hogy az emberek már nincsenek annyira tisztában a csontrendszerben lezajló pozitív változásokkal, hiszen a minta 44,4\%a vélte az úszást hatékonynak csontritkulás esetén, pedig az elósegíti a csontok megvastagodását, teherbíró képességének, szilárdságának és ásványi anyag tartalmának javulását. Ez pedig idős korra erôsebb, teherbíróbb, minőségében jobb csontozatot jelenthet, ami segít megelőzni a csontritkulást.

A szív- és érrendszeri megbetegedések, valamint a daganatos megbetegedések esetén, melyek a leggyakoribb hazánkan, azt az eredményt kaptuk, hogy habár hatásosnak $(70,6 \%)$ tartják az úszást a szív- és érrendszeri megbetegedések kapcsán, de mégsem olyan mértékűnek vélik a szerepét, mint pl. a gerincproblémák esetében. A magas vérnyomás betegség esetében már kevesebben tartják hatásosnak (46,7\%), míg a daganatos megbetegedések esetében a válaszadók mindössze 23,8\%-a tartja lényegesnek. Az elhízás kapcsán a résztveők 75\%-a véli jótékonynak a sportágat, míg a cukorbetegség kapcsán már csak 43,6\%vélekedik így.

A stressz kialakulása ellen is védelmet jelent az úszás, sőt stressz-oldó hatása bizonyított (Bíró, 2011), amit a vizsgálati mintában is magasra értékeltek $(70,6 \%)$ a résztvevők. Az asztma kapcsán viszont a megkérdezettek csupán fele (54,6\%) tartja nagyon, vagy jelentôs mértékben hasznosnak ezt a mozgást, pedig kimondottan hatékony mind az asztmás, mind, pedig az allergiában szenvedôknek. Ez nem teljesen tudott a vizsgálatban résztvevőknél.

Összegzésként azt mondhatjuk, hogy az úszás sokoldalú, pozitív hatásai nagyrészt ismertek az emberek előtt. Ennek ellenére mégis a vizsgálatban résztvevők 38\%-a egyáltalán nem végez ilyen jellegû mozgást, 16,6\%-uk csupán évente, 12,7\%uk félévente, 10,3\%-uk havonta, és mindössze 13,5\%-uk hetente, és 7,9\%-uk naponta. Mi lehet akkor ennek az oka? Ezek, további kutatásra ösztönzőek.

\section{Támogató}

A publikáció elkészítését az EFOP-3.6.2-162017-00003 számú projekt támogatta. A projekt az Európai Unió támogatásával, az Európai Szociális Alap társfinanszírozásával valósult meg.

\section{Irodalom}

Apor, P. (2011): A cardiovascularis kockázat kapcsolata a fizikai aktivitással és a fittséggel. Orvosi Hetilap, 152:107-113. DOI: 10.1556/OH.2011.29022

Bálint, G. (2003): Életminőség és osteoporosis. Ca és Csont, 6:131-133.

Bálint, G. (2007): Csont és ízület évtizede. Reuma biradó, 3:(1):10-12.

Balogh, L., Szabó A., Gáspár Z., Bösze J., Váczi M. \& Kelemen E. (2008): An Analysis of the Components of the 'Psychological Contract' in Interactive Hungarian Team Sports. Current Issues and New Ideas in Sport Science, 2nd International Scientific Conference, cd-kiadvány, Kaunas, Litvánia.

Berger, B. (1994): Coping with Stress: The Effectiveness of Exercise and Other Techniques. Quest, Vol. 46. No. 1. 100-119. DOI: 10.5604/01.3001.0012.6520

Berger, B. \& Owen, D. (1988): Stress Reduction and Mood Enhancement in Four Exercise Modes: Swimming, Body Conditioning, Hatha Yoga, and Fencing. Research Quarterly for Exercise and Sport, Vol. 59. No. 2. 148-159. DOI: $\underline{10.1080 / 02701367.1988 .10605493}$

Bijnen, F. C., Caspersen, C. J., Feskens, E. J., Saris, W. H., Mosterd, W. L., \& Kromhout, D. (1998): Physical activity and 10-year mortality from 
cardiovascular diseases and all causes: the Zutphen Elderly Study. Archives of Internal Medicine, 158(14), 1499-1505. DOI: 10.1001/archinte.158.14.1499

Biró, M., Birone, N. E., Fugedi, B., Revesz, L., Szabo, B. \& Honfi, L. (2007b): Examination of Teaching-Learning Process in Swimming Applying Chaffers' System of Interaction Categories. Educational Research And Reviews (Err) 2:(4) 64-73.

Biró, M., Fügedi B. \& Révész L. (2007a): The Role of Teaching Swimming in the Formation of a Conscious Healthy Lifestyle. International Journal Of Aquatic Research And Education 1:(3). 269-284. DOI: $\underline{10.25035 / \text { ijare.01.03.09 }}$

Bíró, M. (2006) Az úszásnemek megválasztásának és oktatási sorrendjének vízbiztonság és egészség szempontú megközelítése. Iskolai Testnevelés és Sport. 32: 13-20.

Bíró, M. (2006) Tanítási-tanulási stratégiák a mozgásos cselekvéstanítás speciális területén, az úszásoktatásban. Új Pedagógiai S remle, 9: 62-71.

Bíró, M. (2007): Az úszásoktatásban alkalmazott oktatási módszerek fejlődése. Neveléstörténet: $A$ Székessfehérvári Kodolányi János Föiskola Folyoirata 4:(3-4). 100-108.

Bíró, M. (2011): Uszodai sportok - Úszás, Viq alatti sportok, Mü- és toronyugrás, Viq̨ilabda, Kajakpóló, Szinkeronúszás, Aquafitness. Pécsi Tudományegyetem, Szegedi Tudományegyetem, NyugatMagyarországi Egyetem, Eszterházy Károly Főiskola, Dialóg Campus Kiadó-Nordex Kft.,

Biró, M. (2015): A testnevelés aktuális kérdései. In: Révész László, Csányi Tamás (szerk.) Tudományos alapok a testnevelés tanitásához. I. Kötet: szemelvények a testnevelés, a testmozgás és az iskolai sport tárgykoöréböl. Társadalom-, természet- és orvostudományi nézópontok. Budapest: Magyar Diáksport Szövetség, 105-136

Bíró, M., Révész, L. \& Hidvégi P. (2015): Melinda Bíró (szerk.) Krisztina Kaló (ford.); Swimming Eger: EKC Líceum Press.
Bond, D., Lyle R. Tapp, E., M. Seehafer, R. \& D'zurilla, T. (2002): Moderate Aerobic Exercise, T'ai Chi, and Social Problem-Solving Ability in Relation to Psychological Stress. International Jour-nal of Stress Management, Vol. 9. No. 4. 329343. DOI: $10.1023 / \mathrm{A}: 1019934417236$

Bocsi, V. (2017): A gyermeknevelési értékek lehetséges magyarázatai pedagógusjelöltek körében. In: Pálfi, Sándor; Vargáné, Nagy Anikó (szerk.) Kora gyermekekori nevelés szalkmai megújitásának útjai, lehetôségei 1. Debrecen, Magyarország: Debreceni Egyetemi Kiadó. 60-66.

Czeglédi, L. (2018a): Digital collections in physical education (PE). In Jaromír, Šimonek; Beáta, Dobay (szerk.) Sport science in motion: proceedings from the scientific conference. Komárno, Szlovákia : Univerzita J. Selyeho. 244-251.

Czeglédi，L. (2018b): Digitális repozitóriumok, könyvtárak, portálok szerepe a sporttudományok oktatásában. In Balogh, László (szerk.) Fókusz̧ban az egészség. Debrecen, Magyarország: Debreceni Egyetem Sporttudományi Koordinációs Intézet, 50-60.

Cserhátiné, K. E. (2010): A demenciában szenvedő betegek ellátásának társadalmi, egészségügyi és szociális kihívásai. Magyar Gerontológia, 7: 44-56.

Egészségjelentés, $2015.2 \quad$ Nemzeti Egészségfejlesztési Intézet, Budapest.

European Health for all Database (HFA-DB, 2016. december, http://gateway.euro.who.int/ en/data-sources/european-health-for-alldatabase/

Fenyves, V., Bácsné Bába É., Nagy, A. (2020): Közösségben jobb sportolni! A debreceni Campus Sportfesztivál résztvevőinek vizsgálata Debreceni Szemle XXVIII: 1. 112-126.

JAMA, 1996, Physical activity and cardiovascular health. NIH Consensus Development Panel on Physical Activity and Cardiovascular Health, 276: 241246.

Jean, A. (2006) Trends in physical activity and inactivity amongst US 14-18 year olds by gender, 
school grade and race, 1993-2003: evidence from the youth risk behavior survey BMC Public Health 2006, 6:57 DOI: 10.1186/1471-2458-6$\underline{57}$

Juhász, I., Kopkáné, P.J., Kiszela, K., Biró, M., Müller, A. \& Révész, L. (2015): Időskorúak rekreációs fizikai aktivitásának hatása a kardiorespiratorikus rendszerre. Magyar Sporttudományi Szemle 16:(63). 4-8.

Kemper, HC, Post GB, Twisk, JW. \& van Mechelen, W. (1999): Lifestyle and obesity in adolescence and young adulthood: results from the Amsterdam Growth And Health Longitudinal Study (AGAHLS). Int J Obes Relat Metab Disord 1999; 23 (Suppl 3): S34-S40. DOI: $\underline{10.1038 / \text { si.ijo. } 0800881}$

Kerr, J. H. \& Vlas Win Kel, E. H. (1995): Sport Participation at Work: An Aid to Stress Management? International Journal of Stress Management, Vol. 2. No. 2. 87-96.

Kiss, É. Zs. (2003): Fizikai aktivitás. Fittseg - Prevencio. Budapesti Népegésæségügy, 34: 3. 241-247

Kopkáné, P. J., Juhász, I., Müller, A., Biró, M., Hidvégi, P., Kiszela, K. \& Révész L. (2015): Egri időskorúak rekreációs fizikai aktivitásának hatása a kardiorespiratorikus rendszerre Magyar Sporttudományi Szemle 16:(62) 42.

Kopkáné, P.J., Juhász, I., Biró, M., Fodor, É. \& Révész, L. (2015): Egerben élő nyugdíjasok egészségi állapotának és testedzési szokásainak vizsgálata. Acta Academiae Paedagogicae Agriensis Nova Series: Sectio Sport 42: 27-36.

Kőnig-G, D., Szerdahelyi, Z., Czimbalmos-L, N., \& Olvasztóné, B. Zs. (2019): 4-6 éves korú magyar óvodások testi fejlődésének és motorikus szintjének összehasonlító elemzése. In: Pálfi, Sándor (szerk.) Kora gyermekekori nevelés, család és közösségek = Early childhood education, families and communities: Debrecen, Magyarország: Didakt Kft.. 95-107.

Lee, I. M., Rexrode, K. M., Cook, N. R., Hennekens, C. H., \& Buring, J. E. (2001). Physical activity and breast cancer risk: the Women's Health Study (United States). Cancer Causes \& Control, 12(2), 137-145. DOI: 10.1023/a:1008948125076

Laoues, N. (2017): A család és az oktatási intézmény szerepe a fogyatékkal élő gyermekek fejlődésében pp. 19-49. In Vargáné, Nagy Anikó (szerk.) Családi nevelés 2. Debrecen, Magyarország: Didakt Kft.

Magyarország $2015 \quad$ KSH 2016 https://www.ksh.hu/docs/hun/xftp/idoszaki/ mo/mo2015.pdf

Makra, G. \& Balogh, L. (2020): The the analytical tools of dementia, the relationsip between dementia and physical activity - a methodological approach: systematic review.Stadium - Hungarian Journal Of Sport Sciences 3 : 1-16.

Manson, J. E., Hu, F. B., Rich-Edwards, J. W., Colditz G. A., Stampfer M. J., Willett W. C. \& Hennekens C. H. (1999): A prospective study of walking as compared with vigorous exercise in the prevention of coronary heart disease in women. New England Journal of Medicine, 341(9), 650-658.

Martos, É. (1998): Sportélettan. Jákó Péter(szerk.): A sportorvoslás alapjai. Print City Kiadó és Nyomda Kft. Budapest, 31-78.

Mező, K. (2018): A kora gyermekkori családi nevelés hatása az érzelmi intelligencia kialakulására és fejlődésére. In: Vargáné, Nagy Anikó (szerk.) Családi nevelés 3. Debrecen, Magyarország: Didakt Kft.,43-59.

Murray, J.; Teszenyi, E. ; Nagy, V. A.; Pálfi, S.; Marzhan, T. \& Aigul, I. (2019): Parentpractitioner partnerships in early childhood provision in England, Hungary and Kazakhstan: similarities and differences in discourses. In Rentzou, Konstantina; Slutsky, Ruslan (szerk.) Early Childhood Education and Care Quality in Europe and the USA. New York (NY), Amerikai Egyesült Államok: Routledge of Taylor and Francis Group. 104-122. 
Népegészségügyi Jelentés 2008 http://www.oszmk.hu/dokumentum/NEJ/nej 2008 2.pdf

OTÁP 2014 2014-ben az Országos Élelmezés- és Táplálkozástudományi Intézet (OÉTI) által az ELEF 2014 almintáján elvégzett Országos Táplálkozás és Tápláltsági Állapot Vizsgálatban

Piko, B. \& Keresztes N. (2007): Sport, lélek, egészség. Akadémiai Kiadó, Budapest.

Rácz, J. (2005): J/16930. számú tájékoztató a lakosság egészségi állapotáról, valamint a népegészségügyi program 2004. évi előrehaladásáról / előadó

Rockhill, B., Willett, W. C., Hunter, D. J., Manson, J. E., Hankinson, S. E. \& Colditz, G. A. (1999): A prospective study of recreational physical activity and breast cancer risk. Arcbives of internal medicine, 159 (19), 2290-2296. DOI: $10.1001 /$ archinte.159.19.2290

Sagiv, M. (2009): Safety of resistance training in the elderly. Eur. Rev. Aging Phys. Act., 6:1-2 DOI: 10.1007/s11556-009-0047-8

Semsei, I. (2008): Az öregedési folyamat jellemzői. In Semsei I. (szerk.): Gerontológia, 12-15. Start R.V., Nyíregyháza

Somhegyi, A. \& Nanszákne Cserfalvi, I. (2006): Mozgásszegény életmód és a betegségek kapcsolata. In Barabas Katalin, dr. (szerk.): Egészségfejlesztés. Medicina Könyvkiadó Rt., Budapest. 132-138.
Szőts, G., Martos, É., Györe, I., Farkas, A., Jósfay, L., Poór, Gy. \& Mohácsi J. (2004): A fizikai aktivitás és a csontsûrűség összefüggése. Magyar Sportorvos Kongresszus, Budapest.

Tanasescu, M., Leitzmann, M. F., Rimm, E. B., Willett, W. C., Stampfer, M. J. \& Hu F. B. (2002): Exercise type and intensity in relation to coronary heart disease in men. Jama, 288 (16), 1994-2000. DOI: $10.1001 /$ jama.288.16.1994

Tompa, A. (2011): A daganatos betegségek előfordulása, a hazai és a nemzetközi helyzet ismertetése. Magyar tudomány, A Magyar Tudományos Akadémia folyóirata

Wilmore, J. H. \& Costill, D. L. (2004). Physiology of sport and exercise. Champaign, IL: Human Kinetics.

https://www.ksh.hu/docs/hun/xftp/stattukor/hal alozasok07.pdf

https://www.ksh.hu/statszemle archive/2012/20 $1206 / 201206$ 544.pdf

http://www.ksh.hu/docs/hun/xtabla/halalozasok tablha07 03.html

https://ec.europa.eu/eurostat/statisticsexplained/index.php/Causes of death statistics/hu

http://midra.uni-miskolc.hu/document 122114/16453.pdf

https://www.ksh.hu/docs/hun/xftp/idoszaki/pdf Lhalalokistruk.pdf 